\title{
O desenvolvimentismo e seus impactos no meio ambiente
}

\section{Júllia Catharino (estudante de Relações Internacionais - IRI PUC Rio)}

Os séculos $X X$ e $X X I$ foram e estão sendo marcados por um período de grandes desconstruções sociais, como por exemplo as questões relacionadas a gênero, etnia, família, religião, liberdade de expressão, meio ambiente, entre outras muitas questões

As sociedades modernas estão fortemente baseadas nos pilares desenvolvimentistas. O desenvolvimentismo faz parte de uma corrente econômica que preza o crescimento econômico baseado na industrialização e na infraestrutura, com grande presença intervencionista do Estado, e deixando de lado questões sociais importantes.

Como foi dito a cima, essa política desenvolvimentista implica em uma forte industrialização, o que acaba por ter grandes efeitos no meio ambiente, de uma forma geral. $O$ desenvolvimentismo requer grandes intervenções ambientais, como o desmatamento de florestas e de áreas de conservação para a construção de fábricas, de usinas para gerar mais energias, assim como requer a utilização de minerais fósseis como petróleo e carvão, os detritos e gases poluentes produzidos pelas grandes fábricas, o consumismo fora de medida, entre outros fatores que acompanham as grandes políticas desenvolvimentistas.

Porém, nos últimos vinte anos, debates sobre questões ambientais começam a emergir com mais força e passam a ter um maior espaço em meio a grandes convenções políticas, como por exemplo, a Rio-92, a Rio+10 e Rio +20 , sem contar com os grandes acordos que levaram ao Protocolo de Kyoto e a Conferência de Paris. Não obstante ao meio político, os debates acerca da preservação ambiental começam a ganhar espaço na esfera social. 
A preocupação com o meio ambiente é reconhecida pelo Papa Francisco, que em um documento público faz um apelo para que todos os seres humanos protejam a "nossa casa comum", o que significa buscar formas de desenvolvimento sustentável e exalta a luta daqueles que tentam proteger o meio ambiente e resolver “(...) as dramáticas consequências da degradação ambiental na vida dos mais pobres do mundo. (Papa Francisco, 2015)

$\mathrm{Na}$ "Laudato Si", Francisco faz um convite a renovação do diálogo sobre a forma como o futuro do planeta e da nossa sociedade está sendo construído. O Papa diz que é necessário um debate que una todos porque os efeitos da degradação ambiental não possuem efeito sobre o individual, mas sim em cima do coletivo.

"O movimento ecológico já percorreu um longo e rico caminho, tendo gerado numerosas agregações de cidadãos que ajudam na conscientização. Infelizmente, muitos esforços na busca de soluções concretas para a crise ambiental acabam, com frequência, frustrados não só pela recusa dos poderosos, mas também pelo desinteresse dos outros. (...) Todos podemos colaborar, como instrumentos de Deus, no cuidado da criação, cada um a partir da sua cultura, experiência, iniciativas e capacidades" (Papa Francisco, 2015)

A partir da passagem a cima podemos analisar pequenas situações do nosso cotidiano. Afinal, como o próprio Papa disse, a culpa do desmatamento e da degradação ambiental não recai apenas em cima dos poderosos, mas de todos nós. Portanto, se cada um de nós fizesse a sua parte, talvez a situação ambiental atual fosse diferente.

No nosso dia-a-dia nos deparamos com diversas pequenas situações que poderiam nos ajudar a cuidar melhor do nosso planeta. Uma situação bem característica seria, por exemplo, não jogar lixo na rua. As vezes é só um papel de bala, ou um folheto que pegamos na rua e que não nos 
interessou, um cigarro entre outras coisinhas, que as pessoas acabam jogando no chão quando não encontram nenhuma lixeira por perto.

Como foi dito por Francisco na Carta, a raça humana é responsável por cuidar e preservar a nossa casa - o planeta Terra. Segundo o Papa, problemas como esses estão associados com a cultura do descarte, que afeta tanto os seres humanos excluídos como as coisas que se convertem rapidamente em lixo

“(...) Custa-nos a reconhecer que o funcionamento dos ecossistemas naturais é exemplar: as plantas sintetizam substâncias nutritivas que alimentam os herbívoros; estes, por sua vez, alimentam os carnívoros que fornecem significativas quantidades de resíduos orgânicos, que dão origem a uma nova geração de vegetais. (Papa Francisco, 2015)

É preciso que as pessoas comecem a entender que qualquer coisa que seja despejada na natureza, que contrarie os processos naturais, vai acabar mais cedo ou mais tarde, causando um impacto - seja ele grande ou pequeno. Um papel jogado fora de uma lixeira - própria para reciclagem poderá acabar entupindo bueiros e com as chuvas acabar causando enchentes, inundando casas, e desta forma, todo esse lixo acabará chegando aos rios e mares, poluindo assim as águas e todo o ecossistema ali presente.

Outra "coisa" que vem sofrendo com a forte dicotomia produção/consumo é o clima. Essa questão consegue ser ainda mais delicada, porque ainda existem muitos céticos que não acreditam que o aquecimento global está diretamente relacionado ao desenvolvimentismo. Essas mesmas pessoas dizem que as mudanças climáticas e o aquecimento do planeta respeitam um ciclo da natureza. E embora exista um certo teor de verdade por trás deste argumento, já que foi comprovado que o planeta Terra passa por ciclos de calor e frio extremos, as ações humanas contribuem sim para o aceleramento dessas mudanças. 
Os gases produzidos pelas grandes fábricas, os componentes presentes em diversos produtos utilizados por nós no nosso dia a dia, o gás carbônico produzido pela enorme quantidade de veículos a base de gasolina, acabam influenciando no nosso clima e criando situações como o buraco na camada de ozônio, que nada mais é que a destruição das partículas de $\mathrm{O} 3$ - que outrora formavam uma capa protetora contra radiações. A maior parte do buraco se encontra na Antártida e está contribuindo para o derretimento das calotas polares que mais tarde irá vir a causar o aumento do nível dos mares.

Assim como o planeta, o Papa Francisco diz que o clima é um bem comum de todos para todos. As mudanças climáticas são, por sua vez, um problema geral com grandes impactos ambientais, sociais, econômicos e políticos. Apesar de afetar a todos, as consequências de todas essas alterações que vêm acontecendo no meio ambiente tendem a afetar mais fortemente os mais pobres que dependem das agropecuária e de recursos naturais para fazer a sua economia rodar.

Existem muitas pessoas em países como o Brasil, por exemplo, que têm a sua renda mensal quase que completamente baseada na pesca e na plantação, e se continuamos a poluir nossos rios, com papéis e garrafas plásticas, por exemplo, isso terá um impacto direto nesses pescadores, com as grandes quantidades de lixos e resíduos de esgoto que são descartados em rios e lagoas, impedindo os peixes de "respirar". Outro problema, decorrente da poluição das águas, é que nós consumidores desses peixes e frutos do mar acabamos por ingerir alimentos contaminados por todo esse despejo de resíduos e lixo nas águas, gerando problemas graves de saúde.

O principal objetivo desse trabalho é mostrar que toda e qualquer ação afeta o meio ambiente e que este é uma responsabilidade nossa. É nossa responsabilidade cuidar das nossas matas, do nosso ecossistema, preservar a nossa biodiversidade, evitar a produção excessiva de lixo, fazer o 
descarte consciente do lixo produzido - porque este pode ser reaproveitado, ganhando outras funcionalidades. É também parte da responsabilidade do coletivo - e individual - que evitemos produtos que não são aprovados perante as condições ambientais exigidas.

Assim, é de nossa responsabilidade escolher os representantes certos, e exigir dos mesmos que tomem providências efetivas contra o desmatamento de florestas, contra a poluição perpetrada pelas grandes empresas, e até mesmo medidas que tentem inibir certos comportamentos de pessoas que ainda não estão engajadas com as causas ambientais, como é o caso da iniciativa da Prefeitura do Rio de Janeiro que agora multa aqueles que jogam lixo na rua. É nosso dever, como cidadãos, exigir de nossos governantes que forneçam conhecimento e medidas de conscientização para a população, para assim iniciarmos um processo de desconstrução de pensamentos antigos que há muito tempo estão enraizados em nossa sociedade, e assim evoluirmos de uma forma mais "ecofriendly".

Referências Bibliográficas:

- PAPA FRANCISCO. Carta encíclica Laudato Si: do Santo Padre Francismo sobre o cuidado da casa comum. 2015. Disponível em http://w2.vatican.va/content/francesco/pt/encyclicals/docume nts/papa-francesco 20150524 enciclica-laudato-si.html. Último acesso em: 26 de abr 2018 